\section{Burden of disease due to microcephaly associated with the Zika virus in Colombia}

\author{
Carga de enfermedad debido a la microcefalia \\ asociada al virus del Zika en Colombia
}

A carga de doença por microcefalia associada ao
vírus Zika na Colômbia
Andrés Felipe Mora-Salamanca 1

Alexandra Porras-Ramírez 2

Fernando Pio de la Hoz Restrepo 3

\begin{abstract}
In 2015, the Zika virus was introduced in Colombia. The emergence of this arbovirus is a public health challenge for the country, considering the association between the infection and congenital disorders such as microcephaly. Thus, we estimated the burden of disease due to microcephaly associated with Zika in Colombia and its administrative subdivisions for the period 20152016. We conducted an exploratory ecological study, using as unit of measurement disability-adjusted life years (DALYs). The cases of microcephaly were obtained from the Zika national and departmental databases built by the National Public Health Surveillance System (SIVIGILA). Deaths attributed to microcephaly were estimated from previous studies. Finally, we calculated mortality rates and incidences, then we performed a sensitivity analysis under three scenarios (conservative, medium, and extreme) to estimate the DALYs. In the 2015-2016 period, 10,609.4 DALYs were caused by microcephaly associated with Zika in Colombia. 71\% of the total DALYs were years of life lost and $29 \%$ were years lived with disability. Five out of 32 departments (Meta, Córdoba, Tolima, Valle del Cauca, and Norte de Santander) contributed 71\% of total DALYs. The burden of microcephaly associated with Zika outweighed the burden of other congenital anomalies such as neural tube defects and Down syndrome in children aged between 0 and 4 years in Colombia. Public health efforts must be made to prevent and monitor these cases.
\end{abstract}

Microcephaly; Zika Virus; Disability-Adjusted Life Years; Global Burden of Disease

\author{
Correspondence \\ A. F. Mora-Salamanca \\ Av. Calle 80\#73A-21, apto. 231, Bogotá DC, Cundinamarca \\ 111011, Colombia. \\ afmorasa@unal.edu.co \\ 1 Grupo Infecciones y Salud en el Trópico, Universidad Nacional \\ de Colombia, Bogotá, Colombia. \\ 2 Grupo Medicina Comunitaria y Salud Colectiva, Universidad \\ El Bosque, Bogotá, Colombia. \\ 3 Grupo de Epidemiología y Evaluación en Salud Pública, \\ Universidad Nacional de Colombia, Bogotá, Colombia.
}




\section{Introduction}

Although the acute Zika virus infection is generally benign, the virus has been associated with severe complications. Firstly, neurological disorders in general population, especially Guillain-Barré syndrome 1,2. Secondly, congenital anomalies, including congenital microcephaly and fetal losses in women infected during pregnancy 3,4 .

The teratogenic effects of the virus were initially suspected after the increasing number of microcephaly cases reported in Brazil and retrospectively in French Polynesia 5,6. Given the epidemiological and histopathological evidence collected since the first cases of microcephaly and other neurological malformations, currently, the Zika virus can be considered the causal agent of these alterations 3 . Symptomatic and asymptomatic Zika-infected pregnant women are at risk for vertical transmission of the virus. Zika infection during pregnancy can lead to severe birth defects, however, there is a higher risk of congenital anomalies in the first and second trimester of pregnancy 4,7 .

Between 2015 and the first epidemiological week of 2017, 714,636 autochthonous cases were reported in the Americas, out of which 178,297 (25\%) had been confirmed. Brazil and Colombia were the most affected countries, reporting 321,366 and 106,552 cases respectively. During this period, 2,530 cases of microcephaly were reported, out of which $90 \%$ occurred in Brazil 8 .

Epidemiological surveillance of Zika virus disease and its complications in Colombia is conducted by SIVIGILA (Colombia's National Public Health Surveillance System). SIVIGILA records morbidity and mortality of diseases or specific health events such as communicable diseases, nutritional surveillance, chronic non-communicable diseases, congenital defects, maternal and perinatal mortality, external cause injuries and mental health, and mortality in children under five years due to acute diarrheal disease, acute respiratory infection, and malnutrition ${ }^{9}$. These events are recorded in mandatory notification forms. SIVIGILA collects and analyzes those forms, and subsequently generates systematic reports, immediately or weekly 10 . This information guides policies and planning in public health; it is the base for decision-making regarding disease prevention and control, and it also optimizes monitoring and assessment of interventions and rational use of resources available 11.

In Colombia, the first case of Zika reported to SIVIGILA occurred during the epidemiological week 32 of 2015 12. From the introduction of the virus until the end of 2016, a total of 106,659 cases were notified, out of which $18.5 \%$ corresponded to pregnant women (6,363 confirmed cases, 13,383 suspected cases) ${ }^{13}$. Considering the significant number of Zika-infected pregnant women during the 2015-2016 period and the association between infection and the development of microcephaly, we decided to estimate the burden of disease due to microcephaly associated with Zika virus in Colombia, following the methodology proposed by Murray 14 .

\section{Materials and methods}

\section{Type of study}

Ecological exploratory study aimed to estimate the burden of disease due to microcephaly associated with the Zika virus in Colombia, during the years 2015-2016. Disability-adjusted life years (DALYs) were used as unit of measurement and estimated under three scenarios (conservative, medium, and extreme), following the methodology proposed by Murray 14 .

\section{Information sources}

We obtained data on microcephaly cases reported to the SIVIGILA (https://www.ins.gov.co/Direc ciones/Vigilancia/sivigila/) during the 2015-2016 period. Based on the study of Nembhard et al. 15, we estimated the number of deaths caused by microcephaly. According to Nembhard et al. ${ }^{15}$, the firstyear survival rate of microcephaly is $79.7 \%$ (95\%CI: 73.6-84.6).

Demographic data on infants ( $<1$-year-old) both at national and departmental levels for 20152016 were obtained from the National Administrative Department of Statistics (DANE) 16. 


\section{Morbidity and mortality}

Cases of acute Zika virus infection were registered in the SIVIGILA databases under mandatory notification forms 17 . In addition to the acute cases of the disease, these databases also report microcephaly cases related to the infection. Microcephaly is defined as a head circumference more than two standard deviations below the mean for a given sex, age, and ethnicity 18 . Reference values for Colombia are based on the WHO Child Growth Standards and the Resolution n. 2,465 of June 14, 201619.

We counted the microcephaly cases from the SIVIGILA databases according to the department of origin. The result represents the number of cases alive after the first year of life. Incidences per 1,000 infants were calculated at the national and departmental levels. The number of deaths attributed to microcephaly was determined by subtracting the number of cases alive after the first year of life to the number of microcephaly cases reported to SIVIGILA. Mortality rates per 1,000 infants were calculated at the national and departmental levels.

According to the Global Burden of Disease, Zika and congenital Zika syndrome deaths are classified in group I: communicable diseases, maternal and perinatal disorders, and nutritional deficiencies 20 .

\section{Burden of disease (DALYs)}

The burden of disease was expressed in terms of DALYs, following the methodology proposed by Murray 14. DALYs are the sum of the years of life lost (YLLs) and years lived with disability (YLDs). YLLs were estimated based on microcephaly mortality rates by year and department. YLDs were estimated according to parameter values defined in previous studies (Table 1) 15,21,22.

There is no disability weight for microcephaly available. We use the disability weight for severe intellectual disability (disability weight: 0.16) according to Salomon et al. 22 and Alfaro-Murillo et al. 23.

Therefore, we used the duration and survival rates by age (after the first year of life) for intellectual disability (mental retardation) measured by Honeycutt et al. ${ }^{21}$.

\section{Analysis of information}

Statistical analyses and DALYs estimates were performed using Microsoft Excel software (https:// products.office.com/). We use the World Health Organization (WHO) burden of disease templates (https://www.who.int/healthinfo/global_burden_disease/tools_national/en/), following the methodology proposed by Murray 14.

\section{Sensitivity analysis}

DALYs for microcephaly were estimated under three scenarios: conservative, medium, and extreme. The distributions for the parameter values vary by scenario as follows: (1) mortality rate by microcephaly after the first year; and (2) the duration of the disease. The disability weight and the first-year survival rate were constant for the three scenarios (Table 1).

Table 1

Sensitivity analysis parameters.

\begin{tabular}{lcccc}
\hline Parameter & Conservative value & Middle value & Radical value & Reference \\
\hline First year survival rate (\%) & 79.7 & 79.7 & 79.7 & Nembhard et al. 15 \\
Mortality rate after the first year (\%) & 8.0 & 36.4 & 10.7 & Honeycutt et al. 21 \\
Duration of the disease (years) & 25 & 65 & 35 & Honeycutt et al. 21 \\
Weight disability & 0.16 & 0.16 & 0.16 & Salomon et al. 22 \\
\hline
\end{tabular}




\section{Results}

1,119 cases of Zika-associated microcephaly were registered in SIVIGILA during the period 20152016 (2015: 3.7\%; 2016: 96.3\%). 892 cases survived the first year of life, while the remaining 227 cases died during the first year of life (Tables 2 and 3 ).

The mortality rate and incidence of microcephaly associated with Zika nationwide increased 26,2 times from 2015 to 2016. By department, Córdoba had the highest mortality rate and incidence during 2015, while Meta, Tolima, and Córdoba had the highest mortality rate and incidence during 2016 (Tables 2 and 3).

Finally, 10,609.37 DALYs were caused by microcephaly at the national level during the 2015-2016 period (Tables 2 and 3). YLDs accounted for 29\% (3,073.2 YLDs), while the YLLs accounted for 71\% (7,536.17 YLLs) of total DALYs. At the departmental level, Meta, Córdoba, Tolima, Valle del Cauca, and Norte de Santander contributed 71\% of the total burden (Figure 1).

\section{Figure 1}

Disability-adjusted life years (DALYs) due to microcephaly associated with Zika at the departmental level. Colombia, 20152016.

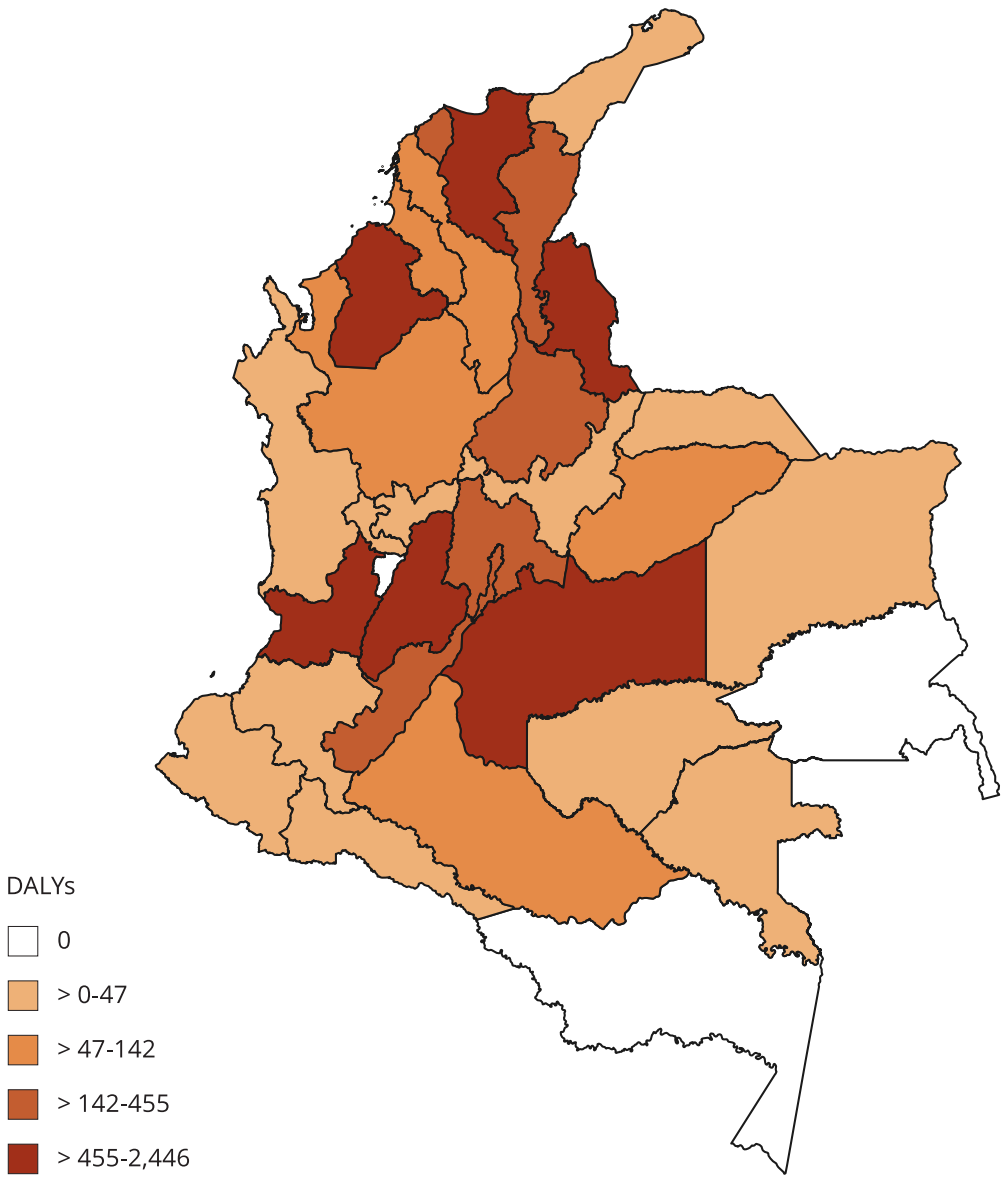

Note: five out of 32 departments (Meta, Córdoba, Tolima, Valle del Cauca, and Norte de Santander) contributed 71\% of total DALYs. 
Regarding sensitivity analysis results, in the conservative scenario at least 10,173.16 DALYs were lost due to microcephaly associated with the Zika virus in the period 2015-2016 at the national level. On the other hand, in the extreme scenario at most 10,860.57 DALYs were lost. The difference between these scenarios is 687.41 DALYs (Tables 2 and 3).

\section{Discussion}

Acute Zika virus infection is usually mild and self-limiting; however, chronic complications represent a public health challenge for Zika-endemic countries. Our results highlight the importance of congenital anomalies related to Zika in Colombia. Out of the 19,746 cases of acute Zika virus disease reported in pregnant women $13,5.7 \%$ of newborns developed microcephaly.

Colombia experienced, especially during 2016, an increase in microcephaly cases compared to previous years. During 2014 and 2015, the number of microcephaly cases per epidemiological week was similar, but in 2016, the cases increased, reaching a peak in the epidemiological week 28 (23 weeks after the peak of acute cases) 24. In 2016 and the first three epidemiological weeks of 2017 the number of microcephaly cases increased compared to the same periods in 2014 and 2015. Therefore, it is possible to argue that the incidence of microcephaly reported during 2016 was associated with the Zika epidemic happening between the epidemiological week 32 of 2015 and the epidemiological week 28 of 2016 (according to SIVIGILA, the epidemiological week 28 of 2016 was the beginning of the endemic phase in Colombia 13).

In our literature review, we only found one published article on the burden of disease due to microcephaly associated with Zika. Alfaro-Murillo et al. 23 estimated 29.95 DALYs lost per every microcephaly case. This value is higher than our estimate (9.48 DALYs). The difference between Alfaro-Murillo et al. 23 estimate and ours is explained by distinct parameter values used for estimating the DALYs (except disability weight) in both studies. Also, their methodology assumes attack rates range between $23.5 \%$ and $77 \%$ and only first-trimester Zika infections can cause microcephaly 23 . On the other hand, their expected microcephaly cases attributable to Zika were based on previous studies, while we used the SIVIGILA database to determine the number of microcephaly cases associated with the Zika virus in Colombia.

In comparison to other diseases, we found that our 2016 microcephaly estimate (10,220.64 DALYs) exceeded the DALYs caused by other congenital anomalies, according to the Global health estimates 2016 published by the WHO 25. For instance, 8,900 DALYs were caused by neural tube defects, 2,700 DALYs by Down syndrome, and 300 DALYs by cleft lip and cleft palate. The burden of Zika-associated microcephaly is comparable to the burden of disease encompassing "other chromosomal anomalies"

Table 2

Estimation under three scenarios of the disability-adjusted life years (DALYs) for microcephaly associated with Zika at departmental and national levels. Colombia, 2015.

\begin{tabular}{|c|c|c|c|c|c|c|c|}
\hline Department & Population * & $\begin{array}{c}\text { Cases reported to } \\
\text { SIVIGILA }\end{array}$ & $\begin{array}{c}\text { Cases } \\
\text { surviving the } \\
\text { first year }\end{array}$ & Deaths & $\begin{array}{c}\text { Conservative } \\
\text { scenario }\end{array}$ & $\begin{array}{l}\text { ALYs } \\
\text { Medium } \\
\text { scenario }\end{array}$ & $\begin{array}{l}\text { Extreme } \\
\text { scenario }\end{array}$ \\
\hline Atlántico & 43,044 & 1 & 1 & 0 & 9.09 & 9.48 & 9.71 \\
\hline Cesar & 22,321 & 1 & 1 & 0 & 9.09 & 9.48 & 9.71 \\
\hline Córdoba & 37,011 & 29 & 23 & 6 & 263.65 & 274.95 & 281.46 \\
\hline Guajira & 26,400 & 1 & 1 & 0 & 9.09 & 9.48 & 9.71 \\
\hline Magdalena & 27,743 & 4 & 3 & 1 & 36.37 & 37.92 & 38.82 \\
\hline Norte de Santander & 25,676 & 5 & 4 & 1 & 45.46 & 47.41 & 48.53 \\
\hline Total Colombia & 873,444 & 41 & 33 & 8 & 372.74 & 388.73 & 397.93 \\
\hline
\end{tabular}

SIVIGILA: Colombia's Public Health Surveillance System.

* Population of infants (< 1 year old) according to the National Administrative Department of Statistics (DANE) 16. 
Table 3

Estimation under three scenarios of the disability-adjusted life years (DALYs) for microcephaly associated with Zika at departmental and national levels. Colombia, 2016.

\begin{tabular}{|c|c|c|c|c|c|c|c|}
\hline \multirow[t]{2}{*}{ Department } & \multirow[t]{2}{*}{ Population * } & \multirow{2}{*}{$\begin{array}{c}\text { Cases reported to } \\
\text { SIVIGILA }\end{array}$} & \multirow{2}{*}{$\begin{array}{c}\text { Cases } \\
\text { surviving the } \\
\text { first year }\end{array}$} & \multirow[t]{2}{*}{ Deaths } & \multicolumn{3}{|c|}{ DALYS } \\
\hline & & & & & $\begin{array}{c}\text { Conservative } \\
\text { scenario }\end{array}$ & $\begin{array}{l}\text { Medium } \\
\text { scenario }\end{array}$ & $\begin{array}{l}\text { Extreme } \\
\text { scenario }\end{array}$ \\
\hline Antioquia & 108,298 & 11 & 9 & 2 & 100.00 & 104.29 & 106.76 \\
\hline Arauca & 6,815 & 2 & 2 & 0 & 18.18 & 18.96 & 19.41 \\
\hline Atlántico & 43,217 & 45 & 36 & 9 & 409.11 & 426.65 & 436.75 \\
\hline Bolívar & 41,801 & 15 & 12 & 3 & 136.37 & 142.22 & 145.58 \\
\hline Boyacá & 21,038 & 5 & 4 & 1 & 45.46 & 47.41 & 48.53 \\
\hline Caldas & 15,615 & 4 & 3 & 1 & 36.37 & 37.92 & 38.82 \\
\hline Caquetá & 11,186 & 6 & 5 & 1 & 54.55 & 56.89 & 58.23 \\
\hline Casanare & 7,352 & 6 & 5 & 1 & 54.55 & 56.89 & 58.23 \\
\hline Cauca & 27,929 & 5 & 4 & 1 & 45.46 & 47.41 & 48.53 \\
\hline Cesar & 22,371 & 23 & 18 & 5 & 209.10 & 218.07 & 223.23 \\
\hline Choco & 13,204 & 1 & 1 & 0 & 9.09 & 9.48 & 9.71 \\
\hline Córdoba & 37,206 & 124 & 99 & 25 & $1,127.32$ & $1,175.66$ & $1,203.49$ \\
\hline Cundinamarca & 49,366 & 20 & 16 & 4 & 181.83 & 189.62 & 194.11 \\
\hline Guajira & 26,778 & 4 & 3 & 1 & 36.37 & 37.92 & 38.82 \\
\hline Guaviare & 2,975 & 1 & 1 & 0 & 9.09 & 9.48 & 9.71 \\
\hline Huila & 23,227 & 45 & 36 & 9 & 409.11 & 426.65 & 436.75 \\
\hline Magdalena & 27,753 & 60 & 48 & 12 & 545.48 & 568.87 & 582.34 \\
\hline Meta & 19,129 & 258 & 206 & 52 & $2,345.56$ & $2,446.13$ & $2,504.05$ \\
\hline Nariño & 33,521 & 2 & 2 & 0 & 18.18 & 18.96 & 19.41 \\
\hline Norte de Santander & 25,685 & 99 & 79 & 20 & 900.04 & 938.63 & 960.85 \\
\hline Putumayo & 8,159 & 2 & 2 & 0 & 18.18 & 18.96 & 19.41 \\
\hline Risaralda & 15,234 & 2 & 2 & 0 & 18.18 & 18.96 & 19.41 \\
\hline San Andrés & 1,299 & 1 & 1 & 0 & 9.09 & 9.48 & 9.71 \\
\hline Santander & 32,976 & 48 & 38 & 10 & 436.38 & 455.09 & 465.87 \\
\hline Sucre & 17,244 & 8 & 6 & 2 & 72.73 & 75.85 & 77.64 \\
\hline Tolima & 25,534 & 143 & 114 & 29 & $1,300.06$ & $1,355.80$ & $1,387.90$ \\
\hline Valle & 73,718 & 136 & 108 & 28 & $1,236.42$ & $1,289.43$ & $1,319.96$ \\
\hline Vaupés & 1,252 & 1 & 1 & 0 & 9.09 & 9.48 & 9.71 \\
\hline Vichada & 2,094 & 1 & 1 & 0 & 9.09 & 9.48 & 9.71 \\
\hline Total Colombia & 876,233 & 1,078 & 859 & 219 & $9,800.42$ & $10,220.64$ & $10,462.64$ \\
\hline
\end{tabular}

SIVIGILA: Colombia's Public Health Surveillance System.

* Population of infants (<1 year old) according to the National Administrative Department of Statistics (DANE) 16.

(10,700 DALYs) 25. In summary, microcephaly associated with Zika was the fourth leading cause of DALYs lost by congenital anomalies in Colombia during 2016.

Regarding Brazil, the country with the highest number of microcephaly cases reported in the world, it is even more difficult to estimate DALYs attributable to this condition. The definition of microcephaly in Brazil changed three times in the 2015-2016 period affecting the number of reported cases 26,27. In Colombia, the prevalence of microcephaly increased fourfold between 2015 and 2016, while Brazil's prevalence increased ninefold compared with the previous 14 years 28 . Consequently, the estimation of the burden of disease caused by Zika-associated microcephaly in Brazil is even more complex than in Colombia.

According to the 57th Epidemiological Report, 2,366 confirmed cases were reported in Brazil between November 8, 2015, and December 31, 2016 29. If we assume that 9.48 DALYs were caused by 
each microcephaly case in Brazil too, the total number of DALYs lost due to microcephaly in Brazil was 22,429.68 DALYs during that period. In comparison with WHO global health estimates 2016, microcephaly surpassed the burden of disease attributable to cleft lip and cleft palate (3,200 DALY) in Brazil 25. However, the number of cases could be even higher, given that 3,183 cases were under investigation at the time the report was published 29 . In the worst-case scenario, DALYs caused by microcephaly could be comparable to DALYs attributable to Down syndrome (33,400 DALY) in Brazil 25.

There are some limitations in this study. Firstly, underreporting affects estimates of the DALYs caused by microcephaly associated with the Zika virus. Surveillance systems are not able to detect every case of Zika virus infection and possibly neither every microcephaly case. Thus, this underreporting translates into an underestimation of the real burden of disease. Generally, Expansion factors are used to correct the underreporting ${ }^{30}$. However, expansion factors have not been estimated for cases of microcephaly related to Zika. On the other hand, considering that the microcephaly diagnosis is relatively simple 18, underreporting should be minimal. Likewise, for February-November 2016, Adamski et al. 31 estimated 1,030 (interquartile range: 650-1,410) infants with congenital microcephaly in Colombia. Their results are comparable to our estimate (1,078 cases of microcephaly). In conclusion, if there is an underreporting of cases, this would probably not be considered significant.

After the first Zika-associated microcephaly case was identified in Brazil, the criteria (head circumference below 2 or 3 standard deviations) used to define microcephaly has been the subject of discussion. We applied the Colombian reference growth curve for head circumference (head circumference below 2 standard deviations) 19. However, abnormal skull shapes and inter-rater differences between clinicians and ultrasonographers may lead to an erroneous diagnosis of microcephaly 32,33 .

It is essential to mention that we focused on one of the most important clinical manifestations of congenital Zika syndrome (microcephaly), however, it does not reflect the entire burden of disease due to congenital anomalies associated with the Zika virus infection. The spectrum of congenital manifestations associated with the Zika virus is broad, and new clinical conditions related to Zika are being described. On the other hand, the risk of occurrence of congenital anomalies caused by the Zika virus infection has not accurately been estimated yet. Previous risk estimates range between 6\% and $42 \% 4,34,35$. Although microcephaly was the most alarming congenital condition identified by the scientific community, the risk of developing microcephaly not as high as it was believed at the beginning of the epidemic. According to Cauchemez et al. 6, the risk of microcephaly increases to about $1 \%$ in pregnant women who get infected during the first trimester. Subsequent analyses indicate that this risk could reach up to $13.2 \%$ 6,36. Other studies have found prevalences of 3.4\%-4\% 4,34. In summary, although microcephaly is a distinctive feature of the congenital Zika syndrome, its presence should raise awareness on the diagnosis and treatment of other congenital anomalies associated with Zika virus infection affecting an endemic community. Similarly, the burden of disease caused by Zika-associated microcephaly represents a fraction of the total burden of disease attributable to the congenital Zika syndrome.

Likewise, cohort studies have revealed that the disability weight for microcephaly must include more clinical manifestations than intellectual disability. The ZODIAC Study (the outcomes of Zika and development in infants and children) is collecting information related to the health and development of children older than 12 months who were born with microcephaly 37 . According to their first preliminary report, $74 \%$ to $79 \%$ of children develop cerebral palsy and severe motor disorders, based on the analysis of a subgroup of 19 children aged 19-24 months. Other less frequent findings are epilepsy, auditory and visual disturbances, and sleep disorders 37 . In conclusion, the real burden of disease due to Zika-associated microcephaly is higher than our results.

On the other hand, van der Linden et al. 38 , conducted a case series of 13 infants who were infected with Zika before birth and normal head size. During the follow-up period, 11 children develop postnatal microcephaly as early as five months of age. Postnatal microcephaly was not included in our estimates since these cases are not reported in mandatory notification forms. SIVIGILA databases were built with forms filled at the moment of diagnosis, either in the emergency room, a prenatal consultation or immediately after childbirth.

The main strengths of the study are as follow: firstly, we had access to primary data (SIVIGILA database). Every microcephaly case should be reported in SIVIGILA; hence, the database accurately reflects the microcephaly situation in Colombia. Secondly, this is one of the first studies to estimate 
the burden of disease due to microcephaly related to the Zika virus infection in Colombia. Lastly, the burden of disease was estimated in three possible scenarios. The range of results obtained will facilitate comparisons with future studies. The entire spectrum of clinical manifestations, especially congenital anomalies caused by the Zika virus infection, have not been identified, so it is not possible to estimate the total burden of disease attributable to Zika. However, we expect that our results will raise awareness among control agencies, not only at the national level but also in all countries affected by the Zika epidemic. Children born to mothers with confirmed or suspected Zika virus infection during pregnancy need long-term monitoring and extensive epidemiological surveillance should be implemented in endemic areas. Likewise, routine screening during pregnancy should be considered in pregnant women at high risk of Zika virus infection.

\section{Conclusion}

This study is the first attempt to estimate the burden of disease due to microcephaly associated with the Zika virus in Colombia. The distribution of the burden of disease was not homogeneous; five out of 32 departments contributed $71 \%$ of the total burden caused by microcephaly. On the other hand, more DALYss were lost due to premature deaths than to chronic cases. This analysis prioritizes the departments requiring further public health action, including prevention, surveillance, and medical care for congenital Zika syndrome in Colombia. Considering the limitations of this study, new research questions emerged to accurately estimate the burden of disease caused by the Zika virus in the future: What is the disability weight of the Zika virus-associated microcephaly? What are the life expectancy and quality of life in patients with Zika virus-associated microcephaly? The Global Burden of Disease and the WHO Global Health Estimates groups should add, in their future burden of disease estimates, the Zika virus infection and its related neurological and congenital anomalies, given its worldwide distribution and its associated morbidity and mortality.

\section{Contributors}

A. F. Mora-Salamanca searched literature, designed the study, performed data analysis, and elaborated the discussion. A. Porras-Ramírez designed the study, performed data analysis, and elaborated the discussion. F. P. H. Restrepo performed data analysis, elaborated the discussion, and reviewed the manuscript.

\section{Additional informations}

ORCID: Andrés Felipe Mora-Salamanca (00000003-1509-0080); Alexandra Porras-Ramírez (0000-0002-0800-1388); Fernando Pío de la Hoz Restrepo (0000-0001-9436-7935).

\section{Acknowledgments}

The authors thank the Colombian National Health Institute for providing the 2015-2016 Zika virus database. 


\section{References}

1. Parra B, Lizarazo J, Jiménez-Arango JA, ZeaVera AF, González-Manrique G, Vargas J, et al. Guillain-Barré syndrome associated with Zika virus infection in Colombia. N Engl J Med 2016; 375:1513-23.

2. Cao-Lormeau VM, Blake A, Mons S, Lastere S, Roche C, Vanhomwegen J, et al. GuillainBarré syndrome outbreak caused by Zika virus infection in French Polynesia. Lancet 2016; 387:1531-9.

3. Rasmussen SA, Jamieson DJ, Honein MA, Petersen LR. Zika virus and birth defects: reviewing the evidence for causality. N Engl J Med 2016; 374:1981-7.

4. Brasil P, Pereira JJ, Moreira M, Nogueira RR, Damasceno L, Wakimoto M, et al. Zika virus infection in pregnant women in Rio de Janeiro. N Engl J Med 2016; 375:2321-34.

5. Oliveira WK, Cortez-Escalante J, De Oliveira WTGH, Carmo GMI, Henriques CMP, Coelho $\mathrm{GE}$, et al. Increase in reported prevalence of microcephaly in infants born to women living in areas with confirmed Zika virus transmission during the first trimester of pregnancy Brazil, 2015. MMWR Morb Mortal Wkly Rep 2016; 65:242-7.

6. Cauchemez S, Besnard M, Bompard P, Dub T, Guillemette-Artur P, Eyrolle-Guignot D, et al. Association between Zika virus and microcephaly in French Polynesia, 2013-15: a retrospective study. Lancet 2016; 387:2125-32.

7. Pacheco O, Beltrán M, Nelson CA, Valencia D, Tolosa N, Farr SL, et al. Zika virus disease in Colombia: preliminary report. N Engl J Med 2020; 383:e44.

8. Pan American Health Organization. Zika suspected and confirmed cases reported by countries and territories in the Americas cumulative cases, 2015-2017. Washington DC: Pan American Health Organization; 2017.

9. Instituto Nacional de Salud. Indicadores para la evaluación de la operación de la vigilancia en salud pública basada en eventos pre definidos. Bogotá: Instituto Nacional de Salud; 2016.

10. Peñaloza R, Salamanca N, Rodriguez J, Rodriguez J, Beltrán A. Estimación de la carga de enfermedad para Colombia, 2010. Bogotá: Editorial Pontificia Universidad Javeriana; 2014.

11. Ministerio de la Protección Social. Decreto no 3.518, de 09 de octubre de 2006. Por el cual se crea y reglamenta el Sistema de Vigilancia en Salud Pública y se dictan otras disposiciones. https://www.minsalud.gov.co/sites/rid/Lists/ BibliotecaDigital/RIDE/DE/DIJ/Decreto3518-de-2006.pdf (accessed on 30/May/2019).

12. Instituto Nacional de Salud. Boletin Epidemiológico Semanal 2015; (52).

13. Instituto Nacional de Salud. Boletin Epidemiológico Semanal 2016; (52).

14. Murray CJL. Quantifying the burden of disease: the technical basis for disability-adjusted life years. Bull World Health Organ 1994; 72:429-45.
15. Nembhard WN, Kim Waller D, Sever LE, Canfield MA. Patterns of first-year survival among infants with selected congenital anomalies in Texas, 1995-1997. Teratology 2001; 64:26775.

16. Departamento Administrativo Nacional de Estadística. Proyecciones de población - estimación y proyección de población nacional, departamental y municipal por sexo, grupos quinquenales de edad y edades simples de 0 a 26 años 1985-2020. https://www.dane.gov.co/ index.php/estadisticas-por-tema/demografia$\mathrm{y}$-poblacion/proyecciones-de-poblacion (accessed on 03/Mar/2019).

17. Instituto Nacional de Salud. SIVIGILA fichas de notificación - dengue - chikungunya Zika. https://www.ins.gov.co/Direcciones/ Vigilancia/sivigila/Paginas/fchas-de-notifica cion.aspx. (accessed on 30/May/2019).

18. Passemard S, Kaindl AM, Verloes A. Microcephaly. In: Dulac O, Lassonde M, Sarnat HB, editors. Handbook of clinical neurology: pediatric neurology part I. London: Elsevier; 2013. p. $129-41$.

19. Ministerio de Salud y Protección Social. Resolución no 2.465 de 14 de junio de 2016. Por la cual se adoptan los indicadores antropométricos, patrones de referencia y puntos de corte para la clasificación antropométrica del estado nutricional de niñas, niños y adolescentes menores de 18 años de edad, adultos de 18 a 64 años de edad y gestantes adultas y se dictan otras disposiciones. https://www. minsalud.gov.co/Normatividad_Nuevo/ Forms/DispForm.aspx?ID=4909 (accessed on 30/May/2019)

20. Murray CJL, Lopez AD, Mathers C; World Health Organization. The global burden of disease: a comprehensive assessment of mortality and disability from deceases, injuries and risk factors in 1990 and projected to 2020. Summary. v. 1. Cambridge: Harvard University Press; 1996.

21. Honeycutt AA, Grosse SD, Dunlap LJ, Schendel DE, Chen H, Brann E, et al. Economic costs of mental retardation, cerebral palsy, hearing loss, and vision impairment. In: Larson S, Barnartt SN, Hendershot GE, Altman B, editors. Using survey data to study disability: results from the National Health Survey on Disability. London: Elsevier; 2003. p. 207-28.

22. Salomon JA, Haagsma JA, Davis A, Noordhout CM, Polinder S, Havelaar AH, et al. Disability weights for the Global Burden of Disease 2013 study. Lancet Glob Health 2015; 3:e712-23.

23. Alfaro-Murillo JA, Parpia AS, Fitzpatrick MC, Tamagnan JA, Medlock J, Ndeffo-Mbah ML, et al. A cost-effectiveness tool for informing policies on Zika virus control. PLoS Negl Trop Dis 2016; 10:e0004743.

24. Pan American Health Organization. Zika-epidemiological report: Colombia. Washington DC: Pan American Health Organization; 2017. 
25. World Health Organization. Global health estimates 2016: disease burden by cause, age, sex, by country and by region, 2000-2016. Geneva: World Health Organization; 2018.

26. França GVA, Pedi VD, Garcia MHO, Carmo GMI, Leal MB, Garcia LP. Congenital syndrome associated with Zika virus infection among live births in Brazil: a description of the distribution of reported and confirmed cases in 2015-2016. Epidemiol Serv Saúde 2018; 27:e2017473.

27. Mocelin HJS, Prado TN, Freitas PSS, Bertolde AI, Perez F, Riley LW, et al. Variação na detecção da síndrome congênita do Zika em função de alterações em protocolos. Rev Panam Salud Pública 2019; 43:e79.

28. Tong VT, Morgan P, Gunturiz ML, MeaneyDelman D, Renquist CM, Mercado M, et al. Preliminary report of microcephaly potentially associated with Zika virus infection during pregnancy: Colombia, January-November 2016. MMWR Morb Mortal Wkly Rep 2016; 65:1409-13.

29. Centro de Operações de Emergências em Saúde Pública sobre Microcefalias. Informe Epidemiológico no 57 - Semana Epidemiológica (SE) 52/2016 (25 a 31/12/2016). Monitoramento dos casos de microcefalia no Brasil. Brasília: Ministério da Saúde; 2017.

30. Shepard DS, Coudeville L, Halasa YA, Zambrano B, Dayan GH. Economic impact of dengue illness in the Americas. Am J Trop Med Hyg 2011; 84:200-7.

31. Adamski A, Honein MA, Ortiz DAC, Martínez MLO, Duarte MAG, Reyes MMM, et al. Estimating the numbers of pregnant women infected with Zika virus and infants with congenital microcephaly in Colombia, 2015-2017. J Infect 2018; 76:529-35.
32. Nunes ML, Carlini CR, Marinowic D, Kalil Neto F, Fiori HH, Scotta MC, et al. Microcephaly and Zika virus: a clinical and epidemiological analysis of the current outbreak in Brazil. J Pediatr (Rio J.) 2016; 92:230-40.

33. Bhushan V, Paneth N. The reliability of neonatal head circumference measurement. J Clin Epidemiol 1991; 44:1027-35.

34. Honein MA, Dawson AL, Petersen EE, Jones AM, Lee EH, Yazdy MM, et al. Birth defects among fetuses and infants of US women with evidence of possible zika virus infection during pregnancy. JAMA 2017; 317:59-68.

35. Reynolds MR, Jones AM, Petersen EE, Lee EH, Rice ME, Bingham A, et al. Vital signs: update on Zika virus - associated birth defects and evaluation of all U.S. infants with congenital Zika virus exposure - U.S. Zika pregnancy registry, 2016. MMWR Morb Mortal Wkly Rep 2017; 66:366-73.

36. Johansson M, Mier-y-Teran-Romero L, Reefhuis J, Gilboa S, Hills S. Zika and the risk of microcephaly. N Engl J Med 2016; 375:1-4.

37. Satterfield-Nash A, Kotzky K, Allen J, Bertolli J, Moore CA, Pereira IO, et al. Health and development at age 19-24 months of 19 children who were born with microcephaly and laboratory evidence of congenital Zika virus infection during the $2015 \mathrm{Zika}$ virus outbreak Brazil, 2017. MMWR Morb Mortal Wkly Rep 2017; 66:1347-51.

38. van der Linden V, Pessoa A, Dobyns W, Barkovich AJ, van der Linden Júnior H, Rolim Filho EL, et al. Description of 13 infants born during October 2015-January 2016 with congenital Zika virus infection without microcephaly at birth - Brazil. MMWR Morb Mortal Wkly Rep 2016; 65:1343-8. 


\section{Resumen}

En 2015, el virus del Zika fue introducido en Colombia. La aparición de este arbovirus es un desafío para el sistema de salud pública del país, debido a la asociación entre la infección y alteraciones congénitas como la microcefalia. Por estas razones, se estimó la carga de la enfermedad, debido a la microcefalia asociada al Zika en Colombia, así como en sus subdivisiones administrativas en el periodo 2015-2016. Se realizó un estudio ecológico de tipo exploratorio, usando como unidad de medida los años de vida ajustados por discapacidad (DALYs, por sus siglas en inglés). Los casos de microcefalia debidos al Zika se obtuvieron de bases de datos nacionales y departamentales, construidas por el Sistema Nacional de Vigilancia en Salud Pública (SIVIGILA). Finalmente, se calcularon las tasas de mortalidad e incidencias, y posteriormente realizamos un análisis de sensibilidad bajo tres escenarios (conservador, medio y extremo), con el fin de estimar los DALYs. Durante el periodo de 2015-2016, se estimaron 10.609, 4 DALYs por microcefalia asociada con el Zika en Colombia. El $71 \%$ de los DALYs correspondieron a los años de vida perdidos y; el restante 29\%, a los años vividos con discapacidad. Cinco de los 32 departamentos de Colombia (Meta, Córdoba, Tolima, Valle del Cauca y Norte de Santander) aportaron el 71\% del total de DALYs. La carga de microcefalia asociada al Zika superó con creces la carga de otras alteraciones congénitas tales como defectos del tubo neural y sindrome de Down en niños entre los 0-4 años en Colombia. Se deben realizar esfuerzos en salud pública para prevenir y monitorear estos casos.

Microcefalia; Virus Zika; Años de Vida Ajustados por la Incapacidad; Carga Global de Enfermedades

\section{Resumo}

O vírus Zika foi introduzido na Colômbia em 2015. O surgimento dessa arbovirose é um desafio para a saúde pública do país, devido à associação entre a infecção e as anomalias congênitas como a microcefalia. Portanto, o estudo buscou estimar a carga de doença pela microcefalia associada ao vírus Zika na Colômbia como um todo e em duas subdivisões administrativas nos anos de $2015 \mathrm{e}$ 2016. Foi realizado um estudo ecológico de tipo exploratório, usando como unidade de medida os anos de vida ajustados para incapacidade (AVAIs). Os casos de microcefalia foram coletados das bases de dados nacionais e departamentais construídos por do Sistema Nacional de Vigilância em Saúde Pública (SIVIGILA). Os óbitos por microcefalia foram estimados a partir de estudos anteriores. Através dos coeficientes de mortalidade e de incidência, realizamos uma análise de sensibilidade em três cenários distintos (conservador, médio e extremo) para estimar os AVAIs. No período de 2015-2016, foram estimados 10.609, 4 AVAIs pela microcefalia associada ao Zika na Colômbia. 71\% dos AVAIs correspondiam aos anos de vida perdidos, e os outros 29\% representavam os anos vividos com incapacidade. Cinco dos 32 departamentos (Meta, Córdoba, Tolima, Valle del Cauca e Norte de Santander) contribuíram com 71\% do total de AVAIs. A carga da microcefalia associada ao Zika ultrapassou a carga por outras anomalias congênitas, como os defeitos do tubo neural e a sindrome de Down em crianças de 0 a 4 anos na Colômbia. São necessárias medidas de saúde pública para prevenir e acompanhar esses casos.

Microcefalia; Zika Virus; Anos de Vida Ajustados pela Incapacidade; Carga Global de Doença
Submitted on $07 /$ Nov/2019

Final version resubmitted on 08/Mar/2020

Approved on 06/Apr/2020 